University for Business and Technology in Kosovo

UBT Knowledge Center

UBT International Conference

2018 UBT International Conference

Oct 27th, $10: 45$ AM - 12:15 PM

\title{
The Impact of Entrepreneurship and Strategic Management in Kosovo SME Sector
}

\author{
Enver Krasniqi \\ University for Business and Technology, enver.krasniqi@ubt-uni.net \\ Sehare Maliqi \\ University of Ljubjana \\ Dea Krasniqi \\ University of Prishtina
}

Follow this and additional works at: https://knowledgecenter.ubt-uni.net/conference

Part of the Business Commons

\section{Recommended Citation}

Krasniqi, Enver; Maliqi, Sehare; and Krasniqi, Dea, "The Impact of Entrepreneurship and Strategic Management in Kosovo SME Sector" (2018). UBT International Conference. 315.

https://knowledgecenter.ubt-uni.net/conference/2018/all-events/315

This Event is brought to you for free and open access by the Publication and Journals at UBT Knowledge Center. It has been accepted for inclusion in UBT International Conference by an authorized administrator of UBT Knowledge Center. For more information, please contact knowledge.center@ubt-uni.net. 


\title{
THE IMPACT OF ENTREPRENEURSHIP AND STRATEGIC MANAGEMENT ACTIVITIES IN KOSOVO SME SECTOR
}

\author{
Enver Krasniqi, Sehare Maliqi, Albina Tafilaj, Dea Krasniqi \\ UBT - Higher Education Institution, Lagjja Kalabria, 10000 p.n., Prishtine, \\ Kosovo \\ University of Ljubjana, Faculty of Economics - Entrepreneurship \\ University of Prishtina, Faculty of Economics
}

\begin{abstract}
This paper examines the impact of Entrepreneurship and Strategic Management Activities in SME sector in Kosovo. The subject was developed based on a broad literature and practices in the SME development sector, and the great importance of strategic activities in regards of firms' growth.
\end{abstract}

While preparing the paper, various methods were utilized for researching and studying strategic economic development, with the focal points in SME development. It is well known that the purpose of strategic development for Entrepreneurship is to develop the capacity for local economic development, to strengthen the future of economy and life quality for all citizens. During this process, the SME sector, public institutions, and partners in the private and nongovernmental sectors cooperate to facilitate economic growth and employment.

This study focuses on enhancing the competitiveness of SMEs in Kosovo, to ensure a sustainable economic growth of the SME sector and the economy. The model includes functions of the internationalization of SMEs, human resources management, innovation strategies of SMEs, information technology and business environment.

The research was conducted by using a sample of BSCK, which was done in 2014 and analysing the results of this research. The primary goal of the study was to define the combination of Entrepreneurship and Strategic Management Activities in creation of joint ventures, and research shows that founders of enterprises use leadership skills and management strategies to increase the firm's assets.

Two basic research questions were defined:

Do entrepreneurs use Strategic Management tools in doing business in Kosovo?

What are the main drivers for choosing Entrepreneurship?

Keywords: strategic activities, SME competitiveness, innovation, orientation towards growth, and business environment.

\section{Problem statement}

Entrepreneurship and strategic management are linked to the behaviour and performance of companies. Strategic management seeks to create and exploit competitive advantages for companies within a particular environmental context. Entrepreneurship promotes the search for competitive advantages by bringing products, processes and innovations to market. 
Entrepreneurial and strategic activities seek new markets or strategic competitive position for firms in order to create profits.

Kosovo is an important location for business development, due to its comparative advantages such as: a young and well-qualified population, natural resources, favourable climatic conditions, new infrastructure, a fiscal policy with the lowest taxation in the region, a geographic position with access to the regional markets, and new possibilities after signing of Stability Association Agreement with the European Union.

Businesses in Kosovo face many managerial issues, which if neglected, will negatively affect their efficiency. Small businesses, in comparison to large ones are more prone to the risk because they are not able to change often, they do not have sufficient capital to contend with the reduction or loss of market revenues, and they have higher operating costs per unit of revenue. But fortunately, one advantage of small businesses is the flexibility and ease of adapting to the nature of changes. This is the reason why they need managerial advice.

\section{Literature Review}

Based on similarities between entrepreneurship and strategic management (Ireland, Hitt, Camp and Sexton, 2001) recommended six areas (Innovation, Networking, Internationalization, Organizational Learning, Top Management Teams and Governance, Growth Orientation) are essential to firms' efforts for profit making. In developing economies, the SME-s are the primary engines of job creation, for income growth and poverty reduction. Therefore, the government should support entrepreneurship as well as business educational aspect for economic development (Krasniqi, 2012). Another important dimension of entrepreneurship literature is the challenge of interaction with the business environment (Begley et al, 2005). As it will be confirmed later, Baumol changed the focus of research from individuals to institutions and the business environment.

It is well known that the purpose of Strategic development for Entrepreneurship is to develop the capacity for local economic development, to improve the economic future and quality of life for all citizens. This is a process in which the SME sector, public institutions, and partners in the private and nongovernmental sectors work together to create better conditions for economic growth and employment.

Firms try to find fundamentally new ways of doing business that will disrupt an industry's existing competitive rules, and lead to the development of new business models that create new forms of competitive life (Hamel, 2000). The degree to which a firm acts entrepreneurially in terms of innovativeness, risk taking, and proactive behaviour is related to dimensions of strategic management (Barringer and Bluedorn, 1999).

This study will explore the meaning and methods that can help CEOs achieve development and growth for their companies in the era of globalization. During the recent few years, the economy of Kosovo has significantly progressed in transitioning to a market-based system and maintaining macroeconomic stability, but the international community and the Diaspora still play an important role for financial and technical assistance. 


\section{Research Methodology}

In order to accomplish this master thesis, methodology was a key factor. The working methodology consists of a combination of primary and secondary data, through examination of literature and empirical studies. In order to accomplish this work, the empirical part relied on collecting and processing data in the field, through surveys. The focus of our survey was on 500 enterprises from different regions of Kosovo. The survey was supported in completing the questions given in a questionnaire designed specifically for this study. The objective of this survey was to take information regarding the work of these SMEs and their contribution to the new jobs opportunities and a specific objective was to find out the impact of Strategic Management in SME sector.

It is worth mentioning that we were a part of BSCK research team in sample development in 2014, and the findings imply that factors such as: SME management, central and local government leadership, conditions of financial sector, structure of the SME sector, the business environment, and approaches to regional markets condition successful Entrepreneurship and SME Strategic Development.

The other objective was to study the business environment where these companies operate and the challenges and obstacles that they face during their operation. During the survey, it was made clear that in the survey be significantly included businesses from all main sectors. The questionnaire was designed in such a manner and form in order to enable the achievement of our goals. The empirical part or the primary data collection was conducted through this survey, whereas the secondary data were collected from the literature of various authors who explicate the same topic subject. Secondary data aim to review the previous studies by various authors and this serves for the realization of the theoretical part of the paper. Types of information, the primary and secondary data, have helped the working methodology in observing the positive effects of the SME development on the economic stability of Kosovo and main constraints that they face during their operation.

More specifically the theses are based on statistical analysis of data collected from a sample developed by the Business Support Centre Kosovo (BSCK) in 2014, including 500 companies in Kosovo (BSCK, 2014). Experts of the field conducted the processes of drafting the questionnaire and sample selection. Interviews were conducted with key persons from companies, mainly managers-owners or financial managers. The questionnaire gathered quantitative and qualitative data (growth motives, firm performance, business environment perception and entrepreneurship and strategic management activities information). A random-selected sample was created from the business register list of the Kosovo Business Registration Agency (KBRA) which is a body of the Ministry of Trade and Industry (MTI). The random selection of sample size and the companies to be interviewed was made by software programs such as Excel TopCaats (Sample and Sample stratification).

After several phases of testing the sample size of selected companies, it was decided to organize the distribution of the sample according to two categories: the size of the company and the sector in which the business operates. In general, the response rates of business managers were from $90-95 \%$ (from 447 - 486 respondents, but in some specific questions, the response rates were lower). 


\section{Data analysis and interpretation}

According to KAS in 2015, about $99.1 \%$ are small and medium enterprises from the total number of enterprises in Kosovo. The structure and growth of SMEs in Kosovo can be seen on the basis of analyses carried out by the SME Agency from Ministry of Trade and Industry.SMEs constitute the backbone of the economy of Kosovo. According to Kosovo Business Registration Agency (KBRA) at the end of 2015, SMEs (including micro enterprises) accounted for approximately $99.97 \%$ of all businesses operating in the country (for more details, see table no. 1).

As the table shows, from 2011 to 2015 the number of SMEs has grown at a rate of about $20 \%$ annually, while the total increase over the past five years was about $35 \%$, but there is no data available on the number of closed and bankrupt SMEs.

Table 1. Enterprises statistics by size $(2011-2015)$

\begin{tabular}{|c|c|c|c|c|c|c|c|c|c|c|}
\hline & 2011 & & 2012 & & 2013 & & 2014 & & 2015 & \\
\hline & No. & $\%$ & No. & $\%$ & No. & $\%$ & No. & $\%$ & No. & $\%$ \\
\hline Mi. Enter. & 6,744 & 96,79 & 8,242 & 97.50 & 9,798 & 97.48 & 9.420 & 98.00 & 9,919 & 98.40 \\
\hline Sm. Enter. & 178 & 2.55 & 160 & 1.89 & 215 & 2.14 & 165 & 1.72 & 139 & 1.38 \\
\hline Med. Ent. & 40 & 0.57 & 43 & 0.51 & 31 & 0.31 & 21 & 0.22 & 19 & 0.19 \\
\hline Total SME & 6,962 & 99.91 & 8,445 & 99.91 & 10,044 & 99.93 & 9,606 & 99.94 & 10,077 & 99.97 \\
\hline Big Enter. & 6 & 0.09 & 8 & 009 & 7 & 0.07 & 6 & 0.06 & 3 & 0.03 \\
\hline Total & 6,968 & $100 \%$ & 8,453 & $100 \%$ & 10,051 & $100 \%$ & 9,612 & $100 \%$ & 10,080 & $100 \%$ \\
\hline
\end{tabular}

GAP Institute, SME Development Strategy for Kosova 2012 - 2016 with Vision to 2020, 2011, p. 4 , Table 1.

\section{Entrepreneurship indicators}

The results from research study are as follows:

- The majority of managers/owners have been employed before they started a business,

- $\quad$ The average of years of experience before they started a business is 7.3; 
- $\quad$ The majority started a business without having a business plan prepared but actually they recognize a value of BP idea to be prepared in advance

- The average of founder age is 32.27 years and mangers/owners age is near 40;

- The opinion about sector growth and firm's profitability is positive and optimistic

- Have been evaluated by SME managers/owners (table no.2).

Table 2. Entrepreneurship indicators - Descriptive Statistic

\begin{tabular}{|c|c|c|c|c|c|}
\hline & $\mathbf{N}$ & Minimum & $\begin{array}{r}\text { Maximu } \\
\mathbf{m} \\
\end{array}$ & Mean & $\begin{array}{r}\text { Std. } \\
\text { Deviation }\end{array}$ \\
\hline $\begin{array}{l}\text { II.10. Have you been employed before you } \\
\text { started business }\end{array}$ & 479 & 1 & 2 & 1.49 & .500 \\
\hline $\begin{array}{l}\text { II.12. years of experience before starting a } \\
\text { business }\end{array}$ & 280 & 0 & 40 & 7.30 & 6.874 \\
\hline II.14 having a BP before starting a business & 494 & 1 & 2 & 1.75 & .432 \\
\hline II.15 Actually do you have a BP & 492 & 1 & 2 & 1.68 & .465 \\
\hline II. 16. A. Founder age & 239 & 16 & 69 & 32.27 & 9.202 \\
\hline II. 16. B. The manager/owner age actually & 308 & 22 & 78 & 39.98 & 10.768 \\
\hline $\begin{array}{l}\text { III.6. What is your opinion about sector } \\
\text { growth where you operate }\end{array}$ & 494 & 1 & 3 & 1.80 & .740 \\
\hline $\begin{array}{l}\text { III.7. What is your opinion about firm's } \\
\text { profitability in your industry }\end{array}$ & 474 & 1 & 4 & 2.37 & .798 \\
\hline Valid N (list wise) & 148 & & & & \\
\hline
\end{tabular}

Note. *Table generated from SPSS Data Analysis Program

The reliability analyses statistics was low (Cronbach's Alpha 0.578 ) and we did not analyse factor data reduction.

Table 3.Reliability Scale for Entrepreneurship indicators

\begin{tabular}{rr}
\hline Cronbach's Alpha & N of Items \\
\hline .578 & 8
\end{tabular}

Note. *Table generated from SPSS Data Analysis Program

The Linear Regression analysis of business barriers on percentage of SME growth compared with last year was significant only by years of experience before starting a business (Significance 0.017 ) and with law significance "Knowledge about sector growth where you operate" significance 0.105 (See table no. 4). 
Table 4. The Linear Data Regression - Coefficients

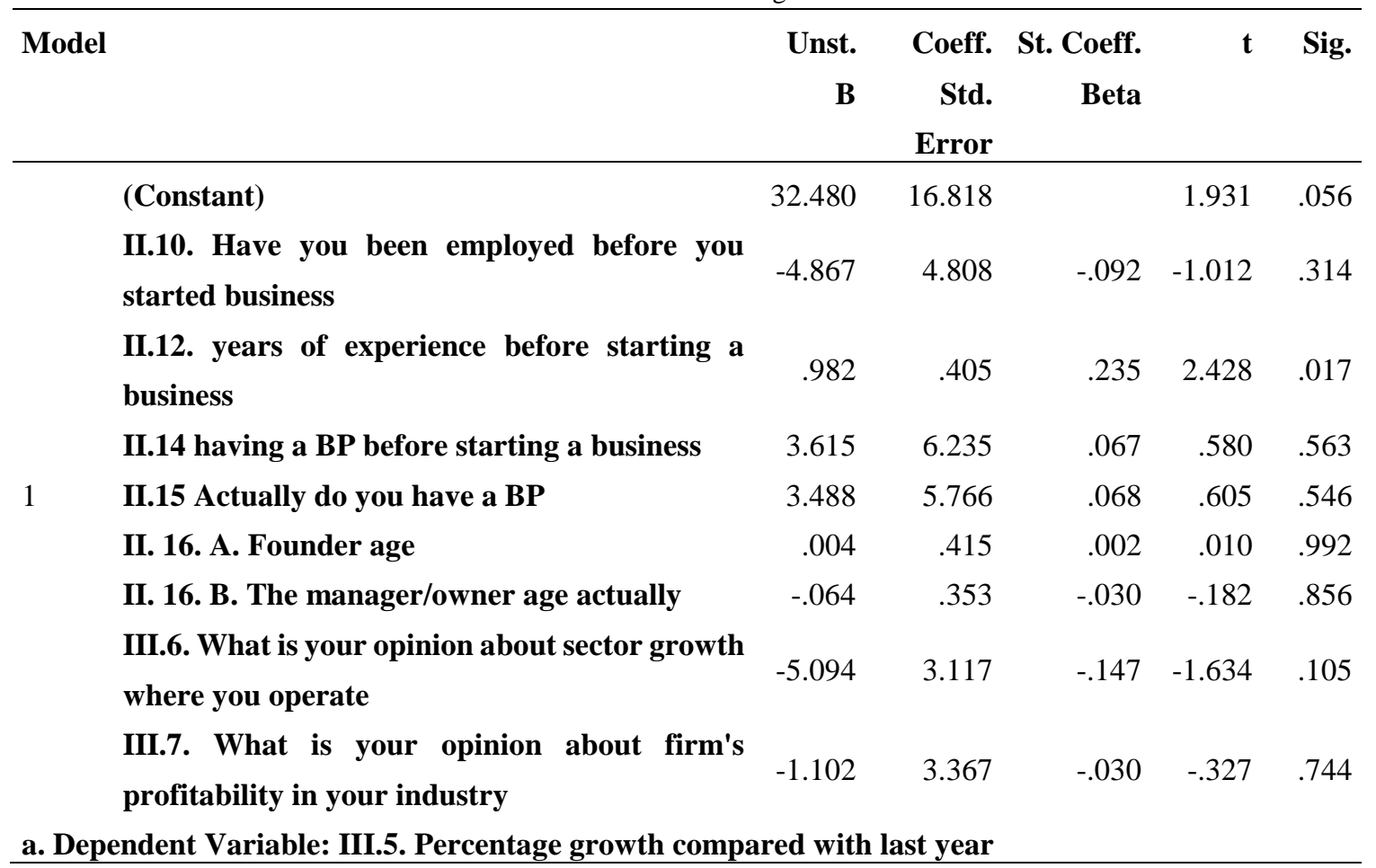

\section{SME Managers - Owners Priorities for Strategic Objectives}

Regarding the descriptive statistics that resulted from respondents' answers, we can conclude that:

- The maximum value of investment was $2,500,000 €$.

- The average of percentage value from the total sales was about $20 \%$ (max. $75 \%$ ),

- The services quality and product image are as priorities for companies (see table no. 5) 
Table 5. Descriptive Statistics

\begin{tabular}{lllrrr}
\hline & N & Minim & Maxim & Mean & Std. Deviat \\
\hline $\begin{array}{l}\text { V.6 Value of investment for next year } \\
\text { VI.6. \% of investment in innovation from the total }\end{array}$ & 281 & 0 & 2500000 & 33844.52 & 178473.02 \\
sells & 84 & 0 & 75 & 19.95 & 18.621 \\
VI.13.1 Strategic goals-product quality & 460 & 1 & 5 & 4.54 & 1.016 \\
VI.13.2 Importance of Product image & 478 & 1 & 5 & 4.59 & .873 \\
VI.13.3 2 Importance of Quality services & 476 & 1 & 5 & 4.69 & .836 \\
VI.13.4 2 Importance of Market share & 465 & 1 & 5 & 4.43 & .861 \\
VI.13.5 2 Importance of Position in industry & 451 & 1 & 5 & 3.93 & 1.282 \\
VI.13.6 2 Imp. of Penetration in international & & & & & \\
market & 366 & 1 & 5 & 2.80 & 1.798 \\
\hline
\end{tabular}

The results about Factor analyses are showed as follows:

1. In the first group are: The product and services Quality and Product image with average of 0.791

2. In the second group was "The position in Industry and Market share and penetration with average 0.691 (See table no. 6).

Table 6. Factor analyses - Component Matrix

Component

1

The Importance of product and services Quality and Product image

VI.13.3 Quality services

VI.13.2 Product image

VI.13.1 Strategic goals-product quality

The Importance of position in Industry and Market share and penetration

VI.13.5 Position in industry

VI.13.6 Penetration in international market

VI.13.4 the market share

Extraction Method: Principal Component Analysis.

a. 2 components extracted.

The Linear Regression analysis of managerial priorities for strategic goals on percentage of SME growth compared with last year was significant 0.00 in "International market penetration" and 0.007 "in given priorities to market share" (See table no. 7) 
Table 7. The Linear Data Regression-Coefficients

\begin{tabular}{llrrrrr}
\hline Model & & \multicolumn{3}{c}{ Unst. Coeff. St. Coeff. } & t & Sig. \\
& & B & Std. & Beta & \\
& & Error & & \\
\hline
\end{tabular}

a. Dependent Variable: III.5. Percentage growth compared with last year

The Linear Regression analysis about decision for investment and value of investment in 2014 and planned value of investment for 2015 on percentage of SME growth compared with last year was significant 0.062 in "Did they invest in 2014?" (See table no. 8)

Table 8. The Linear Data Regression - Coefficients

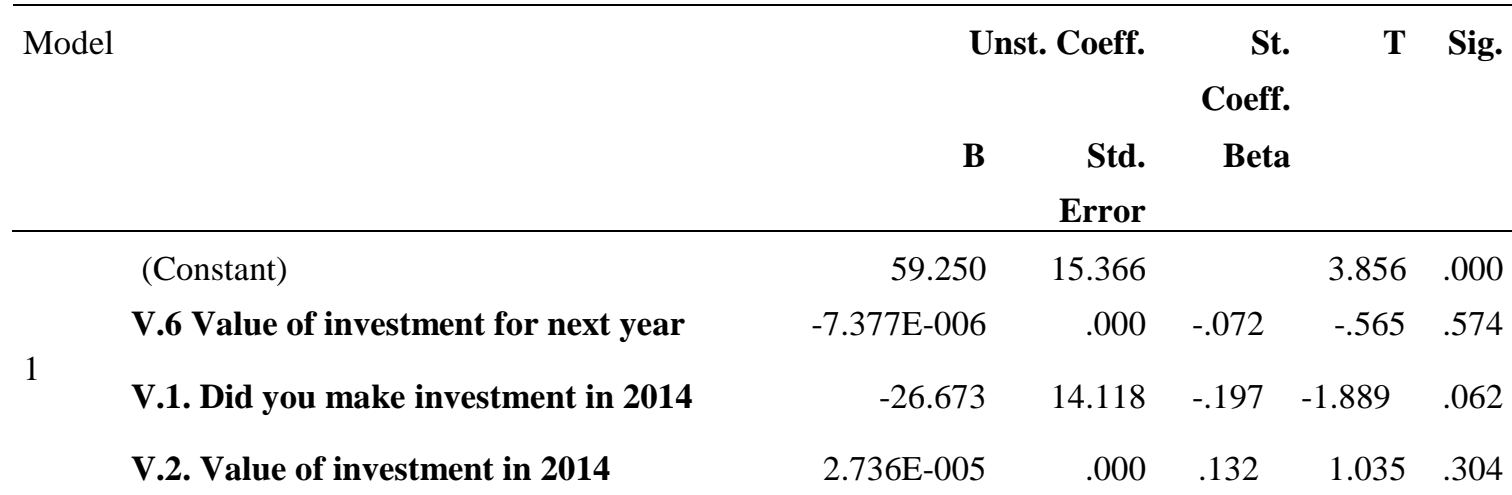

a. Dependent Variable: III.5. Percentage growth compared with the last year 


\section{Discussion of Results, Conclusion and Recommendations}

\begin{tabular}{|c|c|}
\hline Hypothesis & Results \\
\hline $\begin{array}{l}\text { 1. The role of } \\
\text { Entrepreneurship in } \\
\text { SME development } \\
\text { Research questions: What } \\
\text { are the main drivers for } \\
\text { choosing } \\
\text { entrepreneurship? }\end{array}$ & $\begin{array}{l}\text { - SME as main contributors for job creation in Kosovo from 2007- } \\
2013 \text { (about } 118,000 \text { new employees, with the average per year } \\
\text { about 16,800 new employees) } \\
\text { - The role of Entrepreneurship in SME creation. In the period of } \\
\text { 2007-2013, there are 48,908 SME created with average per year } \\
\text { about 7000 businesses } \\
\text { - From the BSCK research, the main drivers for choosing } \\
\text { entrepreneurship are: } \\
\text { - } \quad 32.6 \% \text { of entrepreneurs started a new business to realize their } \\
\text { dreams about business ideas, and } \\
\text { - } 26.13 \% \text { started a business analysing opportunities to realize a } \\
\text { business idea, and } \\
\text { - } 23.97 \% \text { started business because they were jobless. } \\
\text { From SPSS data results, the main drivers for choosing } \\
\text { Entrepreneurship are: } \\
\text { - Years of experience before starting a business, and } \\
\text { - Entrepreneurs knowledge about sector growth where they will } \\
\quad \text { operate }\end{array}$ \\
\hline $\begin{array}{l}\text { The impact of } \\
\text { Strategic } \\
\text { management in SME }\end{array}$ & $\begin{array}{l}\text { Negative results - SME Entrepreneurs in Kosovo are using a } \\
\text { Strategic management tools in low level: } \\
\text { - } \quad \text { Low level of R\&D and Innovations, } \\
\text { - } \quad \text { Low level of creation of new product / service / process, or any } \\
\text { substantial modification of products / services / processes, } \\
\text { - Low level of action to protect intellectual property rights, } \\
\text { - Low level of Companies that did not make any substantial } \\
\text { change to the organizational structure of management, } \\
\text { - Low level of introduction of new product marketing, }\end{array}$ \\
\hline $\begin{array}{l}\text { Research questions: } \\
\text { Do entrepreneurs use } \\
\text { Strategic management } \\
\text { tools in doing business in } \\
\text { Kosovo }\end{array}$ & $\begin{array}{l}\text { Positive results - SMEs are recognising the importance of some } \\
\text { strategic goals: } \\
\text { - Indication about the importance of the following strategic goals; } \\
\text { 1. Service quality } \\
\text { 2. Product \& service image, and } \\
\text { 3. The market share } \\
\text { - SPSS data of Factor analyses: } \\
\text { - The Favourable attitude and Effects from firm's } \\
\text { - Internationalization } \\
\text { - Advantages which helped a firm to compete successfully }\end{array}$ \\
\hline
\end{tabular}


- The Linear Regression Data

- Effects of internalisation for Company development (Significance 0.070)

- Internationalization is a result of our desire to be recognized as a provider of international services (significance 0.176 )

- Effects of firm's internalisation for profit growth (significance 0.193 )

- $\quad$ the new marketing changes (Significance 0.053)

- Did Company register any product rights (Significance 0.104)

- Penetration in international market (Sign. 0.000)

- $\quad$ The market share (Sign 0.007)

- Does company make investment in 2014 (Sign. 0.062)

The private sector in Kosovo consists of micro, small, medium and large enterprises. Despite the fact that sector of SMEs is relatively new, this sector constitutes $99 \%$ of all enterprises in Kosovo, representing a huge potential in the generation of new jobs and economic development. The creation of suitable environment for business and a support of a sustained development of SMEs are the basic conditions for economic development and the growth of social welfare, as well as a source of employment, reformation and productivity. This is the reason that today's main objective of our institutions is working towards increasing and supporting of this sector in order to make it more attractive to young entrepreneurs.

1. The first step is to encourage as many SMEs to enter the formal sector. With the introduction of the regulatory procedures for businesses, a greater number of SMEs will be encouraged to enter the formal economy.

2. The second step is to improve the facilitation of business closure or change of registration forms by ownership. It is extremely important to take initiatives in this area to ensure that honest entrepreneurs are able to start their businesses after they failed in a particular area, or change the form of ownership of their business towards more advanced forms of business development. Having in mind that about $90 \%$ of Businesses are "The Individual Businesses"

3. The Third step is to organize a campaign to strengthen the role of women in the establishment and development of sustainable enterprises.

4. The fourth step that came from our research is improving the "Non-adequate level of employee skills" and "Manager/owner skills"

5. Improving organizational change management and the need for SMEs to be managed by executive managers or management teams is another recommendation, having in mind that about $70 \%$ of SMEs are managed by owners,

6. Business Managers have to agree in providing of training and education to empower their employees in order to support employees in engaging in change-processes

7. Increasing capacities of the senior management team to develop a business vision and mission (short and long term strategic objectives, alternatives and flexible strategies) is another recommendation

8. Increasing competitiveness of products and service quality is an key factor on which businesses should focus because a top barrier for Kosovo SMEs according to our research is "high competition"

9. Increasing awareness about advantages which helped a firm to compete successfully in regional and international market

10. Enforcement of Laws and respecting of contracts according to SMEs unpaid debt (delays) 
11. Increasing awareness about starting a business by analysing opportunities to realize a business idea and starting a business with a prepared business plan.

12. Increasing awareness about importance of business knowledge and experiences

13. More investment in $R \& D$ and Innovations,

14. Increasing knowledge about effects of internationalization for company development,

15. Increasing awareness about importance of product innovations and modifications as well as Protecting Innovations (patent) rights

16. It's recommended firms to use effectively new technology (manufacturing and information technologies), to engage available strategies (using global markets and cooperative strategies),

17. Application of incentives for exports by the government, such as the simplification of bureaucratic procedures, reducing customs tariffs, organizing campaigns to inform businesses for regional and international markets,

18. Strengthening economic ties with other countries in the region, in order to create favourable conditions for the penetration of local products in the regional markets and the European Union.

19. Increasing awareness of entrepreneurs for start-ups to have a prepared Business Plan which can be organized by the Ministry of Trade and Industry and other donors i.e. EU and USAID by financing trainings and other informative methods.

20. Increasing awareness of entrepreneurs for product and services innovations by Ministry of Finance, Ministry of Trade and Industry and other relevant institutions such as Innovation Centre of Kosovo (ICK)

21. Penetration in international market with quality of services especially in different IT services because of the high percentage of youngsters who have multi-language (especially in the English, German, Italian languages) and advanced skills in the IT sector.

22. To increase awareness for product rights registrations by organizing information campaigns from Kosovo Business Registration Agency to inform SME managers about the importance and procedures of the product rights registrations.

\section{Bibliography:}

1. Barringer, B.R., Bluedorn, A.C.. (1999). The Relationship Between Corporate Entrepreneurship And Strategic Management. Strategic Management Journal, 20, 421444.

2. Bussines Support Centre Kosova. (2015). 2014 SME Research. Prishtinë: BSCK.

3. GAP Institute (2011), SME Development Strategy for Kosova 2012 - 2016 with Vision to 2020. Prishtina, GAP Institute.

4. Hamel, G. \& Prahalad, C.K. (2009). Competing for the Future. Cambridge: Harvard Business School Press.

5. Hitt, M. A., Ireland, D. R., \& Hoskisson, E.. (2006). Strategic Management: Concepts and Cases. Thomson South Western: Cengage Learning - Business \& Economics.

6. Ireland, D. R., Hitt, M. A., Camp, M. S., \& Sexton, D. L.. (2001). Strategic entrepreneurship: entrepreneurial strategies for wealth creation. Strategic Management Journal, 22(6-7), 479-491

7. Kosovo Statistical Agency (2015). Statistical Yearbook of the Republic of Kosovo, 2015.Prishtina: Kosovo Statistical Agency 
8. Krasniqi Enver. (2013). Integration of entrepreneurship activities and strategic management of SMEs in Kosovo. Tirana.

9. Krasniqi, B.. (2012). Entrepreneurship and Small Business Development in Kosova (1st ed.). New York: Nova Science Publisher.

10. Ministry of Trade and Industry, MTI, (2014). SME Survey 2014. Prishtina: MTI

11. Task Force for European Integration - Ministry of Europian Integration (2012), Discussion Material of the Field of Industry and SMEs; Retrieved July 14, 2016, http://www.meiks.net/repository/docs/Material_Diskutues_Ndermarrjet_e_Vogla_dhe_te _Mesme.pdf. 